\title{
The Effect of Dynamic Assessment on Grammar Achievement of Iranian Third Grade Secondary School EFL Learners
}

\author{
Samran Daneshfar \\ Faculty of Humanities, University of Zanjan, Zanjan, Iran \\ Seyed Hesamuddin Aliasin \\ Faculty of Humanities, University of Zanjan, Zanjan, Iran \\ Ali Hashemi \\ Faculty of Humanities, University of Zanjan, Zanjan, Iran
}

\begin{abstract}
The present study intends to investigate the effect of dynamic assessment (DA) on EFL learners' grammar knowledge. Based on Murphy, DA originates with the workings of the Russian psychologist and its basis is rooted in his outstanding concept of the zone of proximal development (2008). Embedding instruction and assessment through mediation, DA distinguishes learning potential and promotes development in relation to this potential (Lantolf, 2009, p.360). This study inspects the difference between applying dynamic and nondynamic (static) assessment of Third Grade Secondary School EFL learners' grammar achievement. Therefore, 86 male and female participants (in segregated groups) were investigated to explore the purpose of the study. The consequences of applying DA on both female and male learners, i.e. an experimental and a control group for each gender, were discovered through the current research. First, a pre-test, then a post-test (it was the same as the pre-test) were administered to the applicants to show the possible changes after a period of six mediated sessions. The outcomes of the study presented that dynamic assessment had a significant improvement in participants' grammar achievement.
\end{abstract}

Index Terms-Dynamic assessment (DA), Static assessment (SA), Zone of proximal development (ZPD), mediation, grammar achievement

\section{INTRODUCTION}

Certainly one of the most and critical parts of language learning or any kind of learning a matter is the way the trainer evaluates the learners. According to Poehner (2008) learners and trainers continually complain about the frustration resulted from facing assessment. Changes to the improvement of language teaching, have brought about modifications to the field of language testing. As O'Loughlin (2006, p.72) claims teachers are dealing with the relationship between assessment and learning, stating that the major function of assessment is to bring progress to education. Researchers like Lantolf and Poehner (2008, p.273) have faith in a close association mingling instruction and assessment in which this bond would result from the outstanding approach known as Dynamic Assessment (DA), developed by L.S. Vygotsky. Furthermore, DA connects instruction and assessment, bringing them to a unified activity supporting learners' development through mediation.

In the present study, the researchers examine the effect of Dynamic Assessment vs. non-dynamic assessment on Iranian EFL learners' grammar achievement. Especially, the implementation of DA in this research concerns the results of EFL learners' grammar throughout a period of instruction applying teacher mediation. The researchers intends to explore the influence of embedding instruction with assessment in EFL classroom through mediating the learners.

\section{BACKGROUND}

\section{A. Origins of Dynamic Assessment}

Murphy (2008) and Poehner (2008) state that the origins of dynamic assessment are rooted in the Vygotsky's concept of the zone of proximal development (ZPD) within the sociocultural theory. Vygotsky's ZPD in applied context is defined by the difference between what a child can achieve unassisted and what he/she can accomplish in cooperation with others, both in assessment and in classroom learning situations (Kozulin, Gindis, Ageyev, \& Miller, 2003, p.3). The zone in ZPD is the distance between what a learner can do unassisted and what he/she can achieve in collaboration with a more expert one (Daniels,2001, p.56). Furthermore, the general notion of ZPD based on Chaiklin's (2003, p.40) indication is an interaction between a more competent person and a less knowledgeable one on a task, so that the collaboration will result in the progress of the less competent one. 
Bekka (2010) argues about the significant role of social dealings in language learning programs where ZPD provides a substantial insight into the focuses and practices of language assessment. Based on him the interaction between teachers/assessors and learners in DA builds their ZPD where the learners' learning potential emerges. In other words, to assess a learner's learning potential means to create his or her ZPD through this kind of interaction. On the importance of the ZPD in assessment, Poehner (2008, p.42) claims that Vygotsky proposed this idea as a means of capturing both development and developing abilities. What individuals can do in cooperation with others illustrates their future independent performance. While traditional assessments isolate learners, they should be abandoned in favor of mediated practices during the exam time in order to show their full performance. He continues that because the mediation plays a significant role in the learners' potential growth, this kind of assessment is also an instructional activity. In another study, Lantolf and Poehner (2004, a) prove that DA focuses on promoting development through mediation in ZPD; therefore, it insists on the integration of assessment and instruction.

\section{B. DA vs. Static Assessment}

"Dynamic assessment is an approach to understanding individual differences and their implications for instruction that embeds intervention within the assessment procedure." (Lidz \& Gindis, 2003, p. 99). In this regard, DA can be contrasted with traditional, or static, approaches to testing. The terms static assessment and dynamic assessment were both formulated by researchers working in the DA paradigm in order to distinguish their theoretical perspective from the more traditional models of assessment. The terms refer not to the assessment instruments but to the administrative procedures; any kind of assessment can be conducted in a dynamic or static way. Of course, the terms 'static' and 'dynamic' posit a clear dichotomy between assessments that include intervention and those that do not. (Poehner, 2005, p.14)

Those working in the field of assessment contrast the DA approaches and the traditional approaches to testing. This traditional approach is referred to as static assessment (SA). These terms, SA, and DA do not specifically refer to assessments themselves, but rather to the way in which an assessment is administered. The term "static test" refers to a test where "the assessor presents items to the child and records his or her response without any attempt to intervene in order to change, guide or improve the child's performance" (Tzuriel, 2001, p. 1). Based on Lidz and Gindis' discussion (2003, p.99), dynamic assessment came to the field of assessment as a way of expressing dissatisfaction with the traditional ("product oriented, static") ways of psychological testing. A very vital alteration between DA and SA regards the focus in SA on the product of the past development while DA looks at the upcoming progress. (Poehner and Lantolf, 2003)

Currently, a dichotomous relationship exists between assessment and instruction, therefore; another noteworthy feature of dynamic assessment application is in order to integrate assessment and instruction in which it is not present in SA (Poehner, 2008, p.3). Sternberg and Grigorenko (2002, p. Ix, as cited in Poehner, 2008) argue that DA offers a theoretically motivated method to the unification of assessment and instruction, something of great importance to learners. Considering this, DA procedures are crucial to teachers and students and this importance is because of providing not only scores or grades but insights into the individual's abilities which are the causes of poor performance and specific techniques for supporting development.

\section{Mediation in DA}

As stated above, the idea of intervention or mediation during the course of assessment significantly differentiates dynamic assessment from the so-called traditional or static assessment. Mediation, argued by Haywood and Lidz (2007, p.42), is the method applied by good teachers and parents when they promote high levels of mental functioning in their children and learners. The mediation period displays Vygotsky's ideas about instruction within the zone of proximal development, guiding the assessor in building instructional decisions by analyzing the student, the text, and the type and amount of mediation he/she needs to provide (Vygotsky, as cited in Mardani \& Tavakoli, 2011).

Mediation is an inseparable component of DA procedures and the individual who provides mediation is referred to as the mediator. Vygotsky refers to the mediator as someone who provides "adult guidance" or a "more capable peer". A mediator investigates, questions and provides hints to help a learner do a task that is within his/her ZPD, but which he/she cannot complete alone (Poehner, 2008).

The mediation process can be provided for the learners in several methods. According to Lantolf and Poehner (2004a) there are two primary approaches to DA, Interactionist and Interventionist that usually involve three stages: pre-test, mediation, and then post-test. The difference between these two approaches depends to the way the mediation occurs during the course of assessment.

\section{Interactionist DA}

Interactionist DA as Poehner (2008, p.18) states is rooted in Vygotsky's ZPD where assistance is derived from the interaction between the assessor and the examinee, in relation to the learners ZPD. It focuses on the development of an individual learner or a group of learners, regardless of the effort required and without concern for a predetermined endpoint (Lantolf and Poehner, 2004a). Lantolf and Poehner (2011) argue that in Interactionist DA there is no restriction on mediation and the mediator do whatever possible to aid the learner to go beyond his/her present performance. During interactionist DA leading questions, hints or prompts are not planned in advance; instead, they 
come from mediated dialogue (or collaborative interaction) between the examiner and the examinee in which the examiner responds to the examinee's needs and continually changes his/her mediation.

\section{Interventionist DA}

In interventionist approaches, the tasks and materials are prepared with the objective of predicting the examinee's problems in which will encounter during the course of the assessment. In this approach, mediation is arranged as hints, prompts, and leading questions from implicit to explicit. The mediator follows the hints exactly and moves from hint to hint and the learner chooses the answer he/she thinks is the accurate one (Lantolf and Poehner, 2011). The mediation here can be stated as a standardized one, meaning that the mediation hints are pre-planned to the learners, therefore, all the learners receive the same kind of mediation. Two subcategories make the Interventionist DA: the "sandwich" and the "cake" formats (Sternberg \& Grigorenko, 2002, pp. 27-28). In the sandwich format, the instruction is given all at once between the pre-test and the post-test, whereas in the cake format, the instruction is given in graded layers after each test item, as needed. The key difference between the sandwich format DA and the cake format DA is that instruction and assessment are separate in the former while combined in the latter. (Wang, 2010)

\section{Empirical Studies of DA in L2 Context}

The term dynamic assessment originated in research investigating children's abnormal behaviors and is currently predominantly applied in areas such as learning disabilities or adults' language impairments. However, other practitioners have started to widen the use of dynamic assessment practices to language assessment and pedagogy (e.g., Ableeva 2010, Lantolf and Poehner 2004, Poehner 2005, 2007, 2008, Poehner and Lantolf, 2005). A body of works on DA in the field of Language Learning is presented in this part.

Kozulin and Grab (2002) applied DA in an EFL area to explore the feasibility of the development of DA procedure. They administered a pre-test, mediated learning phase, and a post-test to a group of 23 academically at-risk students who didn't pass the high school English exam. The results of the research indicate that the procedure is both feasible and effective in obtaining information on students' learning potential.

In an important work, Oskoz (2005) explores the possibility of applying dynamic assessment, which focuses on process rather than product, to synchronous computer-mediated communication (SCMC). The study draws on the work of Antón (2003, as cited in Oskoz, 2005), who examined students' performance in oral interaction following DA techniques and on Aljaafreh and Lantolf's (1994 cited in Oskoz 2005) five-level scale (based on the frequency and type of assistance provided to the learner). Antón (2003 cited in Oskoz2005), while assessing learners for placement purposes, proved that this type of assessment is practical in the L2 classroom. The five proposed levels represented different development stages: from other-regulation-when learners trust the tutor's aid to notice and correct an error(levels 1-3) to self-regulation - in which feedback is self-generated and automatic - (level 5), passing by partial regulation - when learners are able to correct an error with minimal or no obvious feedback — (level 4). The study has applied this 5-level scale to students' interaction in SCMC, and analysis of the data showed that it was possible to observe students' potential level of development in an online chat.

Applying DA on reading comprehension by Ajideh and Nourdad (2012) revealed a significant difference between dynamic and non-dynamic assessment with a statistically observable improvement in the reading comprehension scores of the group in which was assessed dynamically. Another study by Jafary, Nordin, and Mohajeri (2012) majorly concerned to investigate the impact of dynamic assessment on learners' syntactic knowledge of Iranian EFL learners. A pre-test, a mediated period, and a post-test were administered to the participants as the three important phases of the study. The analysis of the pre-test and post-test indicated a significant difference between the experimental and control groups, proving that dynamic assessment outperformed in improving syntactic knowledge of the learners.

Nasiri and Khorshidi (2015) explored the effect of dynamic assessment of formulaic sequences in Iranian EFL learners' writing performance. The analysis of the obtained data of their study revealed statistically significant differences between the performances of the participants, who received mediated treatments. They proved that dynamic assessment could improve EFL learners' FSs production in their writing skill. The results of the investigation of the effect of dynamic assessment on Iranian EFL learners' acquisition of English tenses by Abbasi and Fatemi(2015) discovered that the learners in the dynamic group did better than the other group as well as they got a positive attitude toward learning through application of DA. Malmeer and Zoghi (2014) also found significant effect of applying an interactionist model of DA on Iranian EFL adult and teenage learners' grammar performance. Later researchers also investigated the impact of using dynamic assessment on elementary EFL students' grammar learning (Sharifi and Sardareh, 2016). The results of their study proved the usefulness of applying dynamic assessment for grammar learning.

A review of literature shows the importance of using DA to the field of Language learning and bringing improvement to EFL learners' knowledge. Therefore, the present study set out to explore the effect of Dynamic Assessment on Grammar Achievement of Third Grade Secondary School EFL Learners. The main goal of the study is to find whether DA procedures enhance EFL learners Grammar achievement or not. The study is investigating this goal through addressing the following research questions:

1. Does Dynamic Assessment have any effect on the Grammar Achievement of Iranian Third Grade Secondary School EFL Learners?

2. Does the effect of Dynamic Assessment on Grammar Achievement of-Iranian Third Grade Secondary School EFL Learners differ between male and female students? 


\section{METhODOLOGY}

\section{A. Participants}

The participants of the study included both male and female students. The total number of subjects participating in this study was 86 Third Grade Secondary School EFL Learners in Piranshahr. The male and female groups participated in the study as completely separate groups. 43 male students and 43 female students were the subjects of the study. For the selection of the groups of the students for this study, a male school and a female school (schools are segregated in Iran) were randomly selected from all schools of Piranshahr. Then two male classes of Third Grade Secondary School EFL Learners (the researchers was the English teacher of all male and female groups) were selected and also this process took place for the selection of two female classes. The placements of the students in these classes were not altered and remained intact as the placement done by the principals of the schools at the beginning of the education year. The placement procedure of the students in these classes as implemented by the principals of both schools was based on students' grade point average (GPA) for the preceding year. In this method, every classroom is assigned an equal share of the number of students with different GPA to keep the idea of homogeneity in all classes.

To illustrate whether the groups are homogeneous or not, the teacher made test was administered as a t-test to all groups. The results of the t-test proved the homogeneity of the groups, the two male groups were homogeneous and also the two female groups had homogeneity. Table 1 and Table 2 present the results of $t$-test administration. After proving the homogeneity of classes the researchers assigned the classes randomly, to an Experimental Male Group (21students), a Control Male Group (22 students) and also an Experimental Female Group (23 students) and a Control Female Group (20 students).

TABLE 1.

INDEPENDENT SAMPLES T-TEST (PRE-TEST) FOR MALE GROUPS

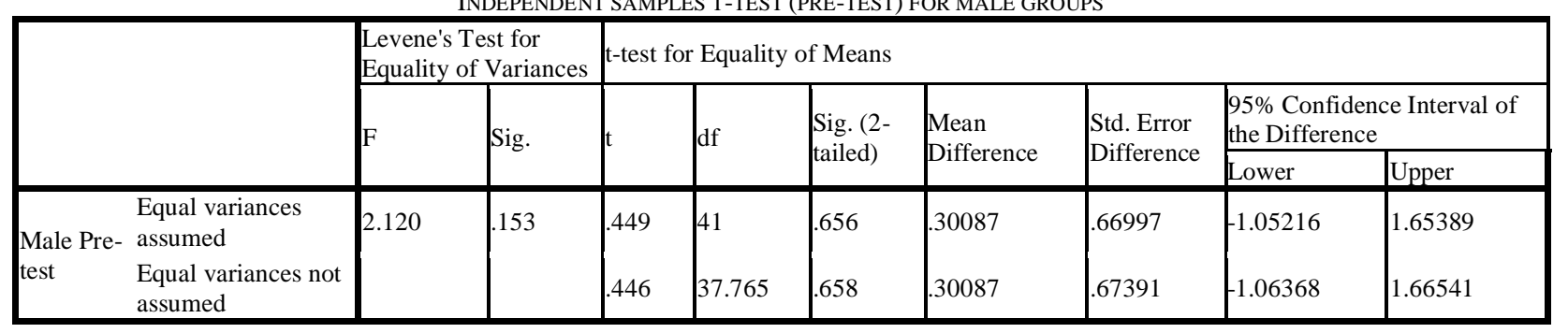

The table represents that the significance level of Levene's test is larger than .05 . In fact, the amount of p-value is $.0656>.05$. It can be concluded that there is no significant difference between the means of the two groups and we can be on the safe side to claim the homogeneity of groups prior to the mediation. Therefore, the researchers was assured that there was no significant difference regarding grammar achievement between the two groups prior to the treatment. So it can be claimed that the two male groups were almost homogeneous in terms of grammar achievement.

TABLE 2.

INDEPENDENT SAMPLES T-TEST (PRE-TEST) FOR FEMALE GROUPS

\begin{tabular}{|c|c|c|c|c|c|c|c|c|c|c|}
\hline & \multicolumn{2}{|c|}{$\begin{array}{l}\text { Levene's Test for } \\
\text { Equality of } \\
\text { Variances }\end{array}$} & \multicolumn{7}{|c|}{ t-test for Equality of Means } \\
\hline & & \multirow[t]{2}{*}{$\mathrm{F}$} & \multirow[t]{2}{*}{ Sig. } & \multirow[t]{2}{*}{$\mathrm{T}$} & \multirow[t]{2}{*}{ df } & \multirow{2}{*}{$\begin{array}{l}\text { Sig. (2- } \\
\text { tailed) }\end{array}$} & \multirow{2}{*}{$\begin{array}{l}\text { Mean } \\
\text { Difference }\end{array}$} & \multirow{2}{*}{$\begin{array}{l}\text { Std. Error } \\
\text { Difference }\end{array}$} & \multicolumn{2}{|c|}{$\begin{array}{l}95 \% \text { Confidence Interval of } \\
\text { the Difference }\end{array}$} \\
\hline & & & & & & & & & Lower & Upper \\
\hline \multirow{2}{*}{$\begin{array}{l}\text { Femal } \\
\text { e pre- } \\
\text { test }\end{array}$} & Equal variances & \multirow[t]{2}{*}{2.595} & \multirow[t]{2}{*}{.115} & 1.059 & 41 & .296 & .60000 & .56658 & -.54424 & 1.74424 \\
\hline & $\begin{array}{l}\text { Equal variances not } \\
\text { assumed }\end{array}$ & & & 1.041 & 35.713 & .305 & .60000 & .57664 & -.56982 & 1.76982 \\
\hline
\end{tabular}

As depicted from the table2, the significance level of Levene's test is larger than .05 , the amount of $p$-value is $.296>.05$. Therefore, it can be concluded that there is no significant difference between the means of the two groups and we can be on the safe side to claim the homogeneity of groups prior to the mediation and the homogeneity of the groups is assured.

\section{B. Instruments}

The instruments used in this study included the teacher made grammar test (TMG) (used both as the pre-test and post-test), and six mediation multiple choice tests. Firstly, the TMG was used to determine the homogeneity of the groups of participants. Secondly, it was used as pre-test and post-test to compare the students before and after the study (before and after the mediation period). This pre-test was a 25 multiple choice grammar test taken mostly from the previous final exams of high school $3^{\text {rd }}$ grade. The test was subjected to 4 experienced EFL teachers' judgments to review them before pretesting (piloting). The test was piloted to a group of 26 EFL learners. Having considered formal 
psychometric analysis — item analysis — the most effective way to increase reliability, the researchers computed item difficulty and item discrimination indices. Item analysis was run on this test and the results showed that seven items were malfunctioning; therefore, these items were deleted (table 3 shows table of specifications after deleting nonacceptable items).

\section{Reliability and validity}

The reliability of the TMG test was estimated through Cronbach's alpha, which turned out to be quite satisfactory (0.826). In order to investigate the validity of the test, the researchers asked for the judgment of 10 experienced EFL teachers teaching the above-mentioned English textbook. They were required to rate the test as very good, good, medium, and weak. Eight of 10 them rated the test as Very Good and only two teachers rated it as Good. Meanwhile, as this pre-test was taken mostly from the previous final exams of high school $3^{\text {rd }}$ grade, it was recognizable enough to credit as it was a test of nation-wide scope.

TABLE 3.

\begin{tabular}{l|l} 
TABLE OF SPECIFICATIONS FOR THE TMG TEST AFTER DELETING NON-ACCEPTABLE ITEMS \\
\hline Contents & Number of Item $\boldsymbol{s}$ \\
- Possessive Forms & 1 \\
- Objective Pronouns & 3 \\
- Quantity Expressions & 2 \\
- Verb forms & 4 \\
1. Simple Past & 2 \\
2. Past Continues & 3 \\
3. Future (will) & 1 \\
- May for permission & 1 \\
- Can for ability & 1 \\
- Should for obligation & 18 \\
Total &
\end{tabular}

The researchers of the study also prepared six mediated multiple choice grammar tests for this study. The content of these tests was completely chosen from students' text book. Each test contained 10 items. These tests were used during the mediation period of the study. The researchers used them as exercises and the scores of these tests were not gathered for the study. The experimental group took one test each session (for six sessions) with the help and mediation from the researchers.

\section{Procedure}

After test preparation, random selection of classes, and proving the homogeneity of all groups the researchers assigned the classes to an experimental and a control group of both the male and female students. Then there were two experimental groups (a male and a female) and two control groups (a male and a female). The male and female groups are completely separated and there is no relation among them.

There were three phases during test administration. First, the pre-test of grammar (TMG test) was administered to all the groups at the beginning of the process. The second was the mediation phase, which took 6 weeks, every week a mediated test was administered to the experimental groups. The interventionist type of mediation was used in this phase. Based on Lantolf and Poehner (2011) in interventionist approaches, the tasks and materials are prepared with the goal of predicting the examinee's problems in which will encounter during the course of the assessment. In this approach, mediation is arranged as hints, prompts, and leading questions from implicit to explicit (the hints were given in Persian, the official language in Iranian schools). The students in experimental groups took a 10-item test in which these items were accompanied by the teachers' prepared help or mediation. Group mediation was given to the students by the researchers due to the lack of time. The way the researchers helped the participants was to give some prepared points orally following the cake format of interventionist DA. In the cake format, the instruction is given in graded layers after each test item, as prepared by the researchers (Sternberg and Grigorenko2002). The hints that the researchers prepared before were what he had decided would be students' problems during the test. Every question was followed by three mediated hints as supposed by the teacher to target the students' needs during the mediation in approaching the correct answer. The hints were not written on students' papers but orally presented and discussed by the assessor to guide the subjects of the research. For the control group, there was no mediation period and they did not take the mediated tests.

In the third step, the post-test (i.e., the same pre-test) was administered to all the experimental and control groups to explore any differences between the experimental and control groups after treatment. As this test was developed in the form of multiple-choice type, the scoring scheme of the test was objective. The test included 18 multiple choice grammar items (each item including a stem and four choices). Every correct response was assigned a score of 1; therefore, the total (or possible highest) score of a participant on the test would be 18. The participants' mean scores on the posttest were obtained in all the experimental and control groups and comparisons between the groups were performed appropriate statistical procedures describes below.

\section{Data Analysis}


The data collected through the teacher made grammar test (i.e. pre-test and post-test) were analyzed using the statistical software SPSS. First, the pilot study for teacher made grammar test (multiple-choice grammar pre-test/ posttest) was carried. Then, descriptive statistics (table 4), including minimum, maximum, mode, median, mean, standard deviation, and variance were calculated. For inferential statistics, an independent samples t-test was employed. Through the application of the t-test, the mean scores of the subjects in the experimental groups were compared with the mean scores of the subjects in the control groups (both male and female groups). This was done to show any significant difference between experimental and control groups' grammar achievement. To investigate the second research question, the researchers compared the post-test mean scores of both female and male experimental groups to show whether there is any difference between male and female learners grammar achievement after implementing DA.

TABLE4.

DESCRIPTIVE STATISTICS

\begin{tabular}{|c|c|c|c|c|c|c|c|c|}
\hline & \multicolumn{2}{|l|}{$\begin{array}{l}\text { Male } \\
\text { Pre-test }\end{array}$} & \multicolumn{2}{|l|}{$\begin{array}{l}\text { Male } \\
\text { Post-test }\end{array}$} & \multicolumn{2}{|l|}{$\begin{array}{l}\text { Female } \\
\text { Pre-test }\end{array}$} & \multicolumn{2}{|l|}{$\begin{array}{l}\text { Female } \\
\text { Post-test }\end{array}$} \\
\hline & Exp. & Control & Exp. & Control & Exp. & Control & Exp. & Control \\
\hline $\begin{array}{l}\text { Valid N } \\
\text { Missing } \\
\text { Mean } \\
\text { Median } \\
\text { Mode } \\
\text { Std. Deviation } \\
\text { Variance } \\
\text { Minimum } \\
\text { Maximum } \\
\text { Sum }\end{array}$ & $\begin{array}{l}21 \\
0 \\
9.6190 \\
9.0000 \\
8.00 \\
2.45919 \\
6.048 \\
6.00 \\
14.00 \\
202.00\end{array}$ & \begin{tabular}{|l}
22 \\
0 \\
9.3182 \\
9.5000 \\
$9.00^{\mathrm{a}}$ \\
1.91203 \\
3.656 \\
5.00 \\
12.00 \\
205.00
\end{tabular} & $\begin{array}{l}21 \\
0 \\
11.6667 \\
12.0000 \\
12.00 \\
2.86938 \\
8.233 \\
8.00 \\
19.00 \\
245.00\end{array}$ & $\begin{array}{l}22 \\
0 \\
9.0909 \\
9.0000 \\
8.00^{\mathrm{a}} \\
1.63034 \\
2.658 \\
6.00 \\
12.00 \\
200.00\end{array}$ & $\begin{array}{l}23 \\
0 \\
10.0000 \\
10.0000 \\
10.00 \\
1.62369 \\
2.636 \\
7.00 \\
14.00 \\
230.00\end{array}$ & $\begin{array}{l}20 \\
0 \\
9.4000 \\
9.0000 \\
8.00 \\
2.08756 \\
4.358 \\
6.00 \\
13.00 \\
188.00\end{array}$ & $\begin{array}{l}23 \\
0 \\
12.8261 \\
12.0000 \\
12.00^{\mathrm{a}} \\
1.58551 \\
2.514 \\
10.00 \\
16.00 \\
295.00\end{array}$ & $\begin{array}{l}20 \\
0 \\
9.8000 \\
10.0000 \\
10.00^{\mathrm{a}} \\
1.76516 \\
3.116 \\
6.00 \\
12.00 \\
196.00\end{array}$ \\
\hline
\end{tabular}

a. Multiple modes exist. The smallest value is shown

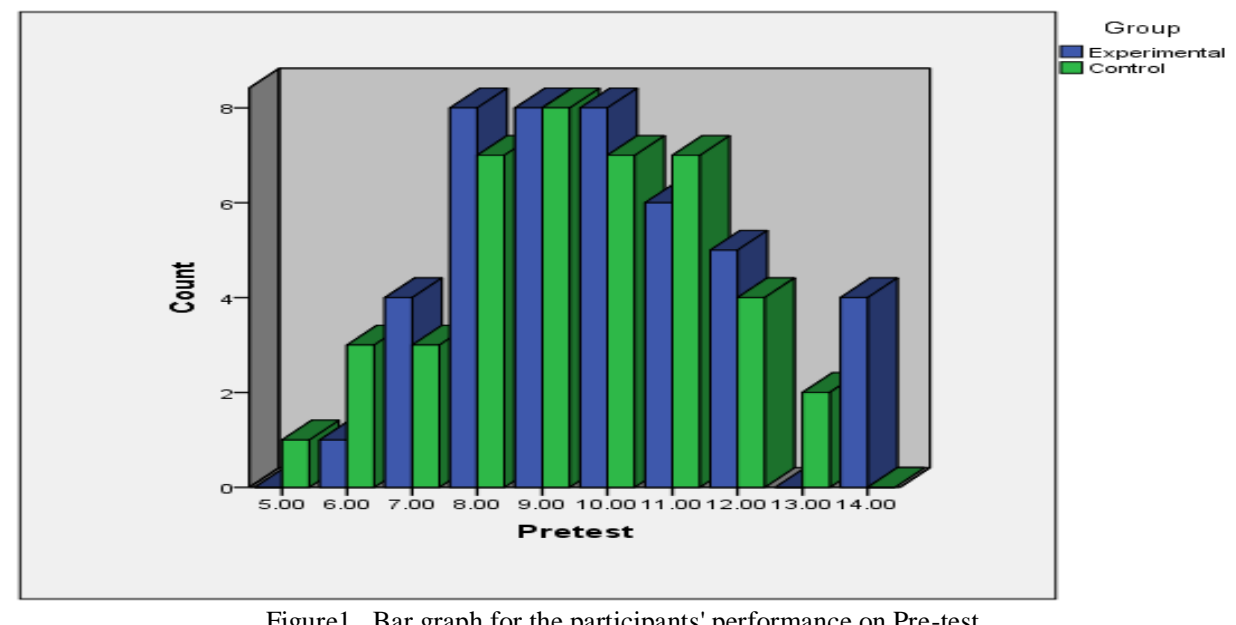

Figure1. Bar graph for the participants' performance on Pre-test

\section{E. Results of the Analyses}

The results of the study are presented in two sections. To answer the first research question, independent samples ttest analyses for both male and female groups are presented separately. Then, to investigate the second research question, the independent sample t-test analyses for two experimental groups (male and female) are conducted.

\section{Independent-samples T-test results for post-test means}

\subsection{T-test results for male groups on post-test}

To examine the data further, group statistics and t-test is utilized. Independent samples t-test is used to compare the mean scores of the experimental and control male groups post-test. In simple terms, the t-test compares the actual difference between two means in relation to the variation in the data. Here, the difference in the post-test of male participants in the experimental and control groups are compared.

TABLE5.

GROUP STATISTICS FOR MALE GROUPS POST-TEST

\begin{tabular}{|c|c|c|c|c|}
\hline M Group & $\mathrm{N}$ & Mean & Std. Deviation & Std. Error Mean \\
\hline $\begin{array}{ll}\text { Male post- } & \text { Experimental Male } \\
\text { test } & \text { Control Male }\end{array}$ & 21 & $\begin{array}{l}11.6667 \\
9.0909\end{array}$ & $\begin{array}{l}2.86938 \\
1.63034\end{array}$ & $\begin{array}{l}.62615 \\
.34759\end{array}$ \\
\hline
\end{tabular}


TABLE 6.

INDEPENDENT SAMPLES T-TEST FOR MALE GROUPS POST-TEST

\begin{tabular}{|c|c|c|c|c|c|c|c|c|c|c|}
\hline & & \multicolumn{2}{|c|}{$\begin{array}{l}\text { Levene's Test for } \\
\text { Equality of Variances }\end{array}$} & \multicolumn{7}{|c|}{ t-test for Equality of Means } \\
\hline & & \multirow[t]{2}{*}{$\mathrm{F}$} & \multirow[t]{2}{*}{ Sig. } & \multirow[t]{2}{*}{$\mathrm{t}$} & \multirow[t]{2}{*}{ df } & \multirow{2}{*}{$\begin{array}{l}\text { Sig. }(2- \\
\text { tailed) }\end{array}$} & \multirow{2}{*}{$\begin{array}{l}\text { Mean } \\
\text { Difference }\end{array}$} & \multirow{2}{*}{$\begin{array}{l}\text { Std. Error } \\
\text { Difference }\end{array}$} & \multicolumn{2}{|c|}{$\begin{array}{l}95 \% \text { Confidence Interval } \\
\text { of the Difference }\end{array}$} \\
\hline & & & & & & & & & Lower & Upper \\
\hline \multirow{2}{*}{$\begin{array}{l}\text { Male } \\
\text { post-test }\end{array}$} & $\begin{array}{l}\text { Equal variances } \\
\text { assumed }\end{array}$ & \multirow[t]{2}{*}{2.298} & \multirow[t]{2}{*}{.144} & 3.641 & 41 & .001 & 2.57576 & .70747 & 1.14698 & 4.00453 \\
\hline & $\begin{array}{l}\text { Equal variances not } \\
\text { assumed }\end{array}$ & & & & 31.387 & .001 & 2.57576 & .71616 & 1.11587 & 4.03564 \\
\hline
\end{tabular}

Considering table6, the computed amount of $t$ is 3.641 also the significance level of Levene's test $(.001<.05)$. This shows that there is an important difference between experimental and control male groups post-test mean scores. Also based on table6, the results of the t-test showed that the experimental male group outperformed the control male group in the post-test. Therefore, we conclude that Dynamic Assessment improved male students' grammar achievement.

\subsection{T-test results for female groups on post-test}

To see if there was any significant difference between the mean scores of experimental and control female groups on post-test administration, an independent samples t-test was run. Considering table 8, the computed amount of $\mathrm{t}$ is 5.923 also the significance level of Levene's test $(.0000<.05)$. This shows that there is a significant difference between experimental and control female groups post-test mean scores. Also based on table 8, the results of the t-test showed that the experimental female group outperformed the control female group in the post-test. Therefore, we conclude that Dynamic Assessment improved female students' grammar achievement.

TABLE7.

GROUP STATISTICS FOR FEMALE GROUPS POST-TEST

\begin{tabular}{|l|l|l|l|l|l|}
\hline & F Group & N & Mean & Std. Deviation & Std. Error Mean \\
\hline \multirow{2}{*}{ Female post-test } & Experimental F & 23 & 12.8261 & 1.58551 & .33060 \\
& Control F & 20 & 9.8000 & 1.76516 & .39470 \\
\hline
\end{tabular}

TABLE8.

INDEPENDENT SAMPLES T-TEST FOR FEMALE GROUPS POST-TEST

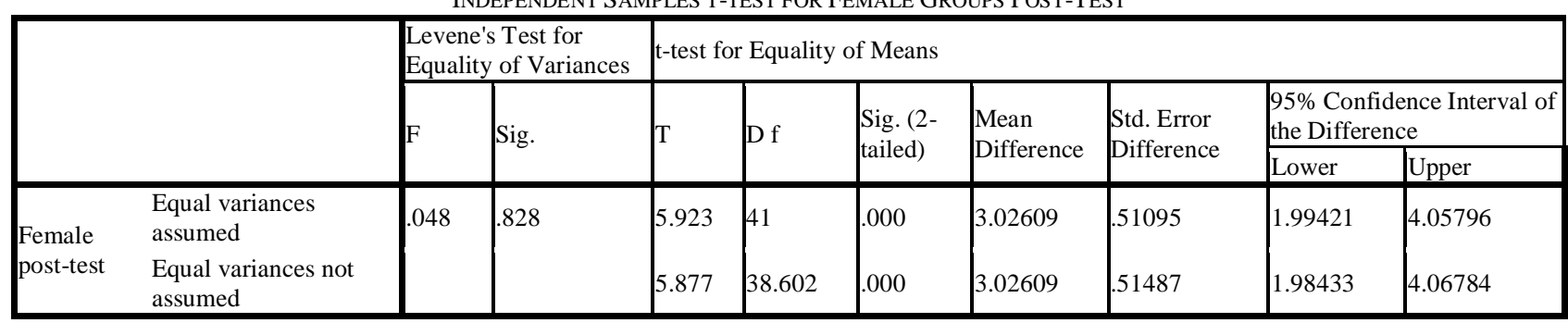

\section{Post-Test Mean Scores of Female and Male Experimental Groups}

In order to investigate if DA differs between male and female EFL learners' grammar achievement, an independent samples t-test was applied to both experimental groups. Table 10 shows that the computed t value and the significance level of Levene's test $(.0000<.05)$ show that there is no significant difference between the mean scores of the experimental male and female. From the results, it can be concluded that Dynamic Assessment improves both female and male students' grammar achievement.

TABLE9.

Group STATISTICS FOR EXPERIMENTAL FEMALE AND MALE GROUPS POST-TeST

\begin{tabular}{|ll|l|l|l|l|}
\hline & Groups & N & Mean & Std. Deviation & Std. Error Mean \\
\hline \multirow{2}{*}{ Post-test } & Male & 21 & 11.6667 & 2.86938 & .62615 \\
& Female & 23 & 12.8261 & 1.58551 & .33060 \\
\hline
\end{tabular}

TABLE10.

INDEPENDENT SAMPLES T-TEST FOR EXPERIMENTAL FEMALE AND MALE GROUPS POST-TEST

\begin{tabular}{|c|c|c|c|c|c|c|c|c|c|c|}
\hline & & \multicolumn{2}{|c|}{$\begin{array}{l}\text { Levene's Test for } \\
\text { Equality of Variances }\end{array}$} & \multicolumn{7}{|c|}{ t-test for Equality of Means } \\
\hline & & \multirow{2}{*}{$F$} & \multirow{2}{*}{ Sig. } & \multirow[t]{2}{*}{$\mathrm{t}$} & \multirow{2}{*}{ df } & \multirow{2}{*}{$\begin{array}{l}\text { Sig. (2- } \\
\text { tailed) }\end{array}$} & \multirow{2}{*}{$\begin{array}{l}\text { Mean } \\
\text { Difference }\end{array}$} & \multirow{2}{*}{$\begin{array}{l}\text { Std. Error } \\
\text { Difference }\end{array}$} & \multicolumn{2}{|c|}{$\begin{array}{l}95 \% \text { Confidence Interval } \\
\text { of the Difference }\end{array}$} \\
\hline & & & & & & & & & \begin{tabular}{|l|} 
Lower \\
\end{tabular} & Upper \\
\hline \multirow{2}{*}{ Post-test } & $\begin{array}{l}\text { Equal variances } \\
\text { assumed }\end{array}$ & \multirow[t]{2}{*}{3.547} & \multirow[t]{2}{*}{.067} & -1.679 & 42 & .101 & -1.15942 & .69073 & -2.55338 & .23454 \\
\hline & $\begin{array}{l}\text { Equal variances } \\
\text { not assumed }\end{array}$ & & & -1.637 & 30.547 & .112 & -1.15942 & .70807 & -2.60440 & .28556 \\
\hline
\end{tabular}




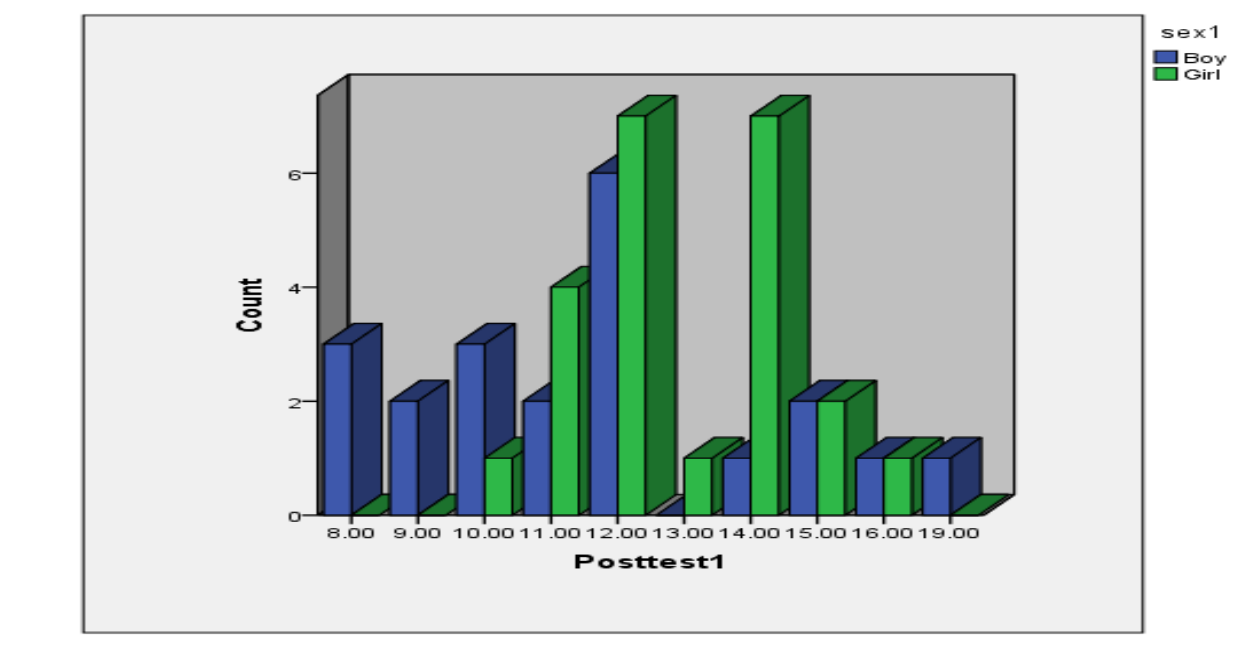

Figure 2. Bar graph for the male and female participants' performance on the posttest within the experimental group.

\section{DISCUSSION}

The aim of this study was first to explore the possibility of the development of DA on Iranian EFL learners, grammar achievement and it also explored whether DA improves both male and female EFL learners' grammar achievement in Iran or not. Two completely separate groups of male and female EFL learners participated in the study. A comparison of the mean score of experimental male group displayed that the mean score of the experimental male group had an increase of 2.05 score in post-test while the control male group had a decrease of -0.5. Also, the comparison of the mean score of the experimental female group showed that the mean score of the experimental female group had an increase of 2.82 scores in post-test while the control female group had only an increase of 0.4 scores. These analyses showed that both female and male learners in the experimental groups performed better in comparison with the learners in the control groups.

To explore the second research question which investigates if DA affects both male and female groups in the same direction or not, the experimental groups' mean scores proved that both experimental groups positively improved in the post-test. In addition, the implication of independent samples t-test to two experimental groups, the computed $t$ value, and the significance level of Levene's test $(.0000<.05)$, showed that there is no significant difference between experimental male and female samples t-test (post-test) scores. Therefore, the implementation of DA to both male and female EFL learners' grammar achievement had a positive effect and results significantly in their development.

Another important finding of the study was that dynamic assessment groups and non-dynamic assessment ones from pre-test to post-test performed significantly. The results proved that all groups except control male group positively improved during the study, but the changes for experimental groups were outstanding. The comparisons of pre-test and post-test scores showed significant changes just for DA groups. These results illustrate the effectiveness of implementing DA to learners' grammar achievement. Comparing the findings of this study and other similar studies, it is concluded that findings of the present study confirm other studies as indicating that DA is an effective approach to language learning, especially in this research the grammar knowledge of students.

\section{CONCLUSION}

The purpose of this study was to explore the effect of implementing dynamic assessment on grammar achievement of Iranian Third Grade Secondary School EFL learners. The study proved that there is a significant difference between the improvement of experimental and control groups of both male and female learners. The study administered a pre and post-test (they were the same) to the participants to show the change after a period of six mediated sessions. The mediation presented to the learners followed Sternberg and Grigorenko's (2002) cake format of interventionist approach to DA. In the interventionist cake format, the instruction, help, is given to the learners in graded layers after each test item.

To determine this implementation, the results of the groups' pre-test were compared with the results of their performance at the post-test. Application of t-test to the groups showed that there is a significant increase in the performance of male and female learners in experimental groups; this means that learners in experimental groups outperformed learners in control groups. The results indicate that DA procedure improves EFL learners' grammar achievement. The study answers two research questions; first, it proved that implementing dynamic assessment procedure significantly improves EFL learners' grammar knowledge in comparison to the so called non-dynamic (static) assessment. The study also proved that implementing dynamic assessment procedure to both male and female learners had a positive effect and improves their grammar knowledge. 


\section{PEDAGOGICAL IMPLICATIONS OF THE STUDY}

Lidz and Gindis (2003) believe that DA is an approach to understanding individual differences and their implications for instruction, focusing on intervention within the assessment procedure. The major concern of the present study has been to implement dynamic assessment in the EFL classroom settings. Therefore, the findings of the study can carry some useful pedagogical implications.

Negotiated interactions in the L2 learning context can help the EFL learners solve their problems and perform better. DA was presented within the context of a pedagogical task, rather than during the administration of a formal test. This has direct implications for the EFL classroom activities, where the teacher's assessment of the learners' achievement rate often leaves them with ample problems. The study findings imply that DA principles can make EFL classroom assessment practices more effective by providing assistance to the learners in line with their needs.

Teachers, for instance, can help EFL learners to improve their grammar achievement by mediating them during the exam. Therefore, they let the learners find out their problems with these mediations and to find the best ways to reach the answers. This also helps the learners to benefit more from dynamic assessment sessions to improve their grammatical knowledge than the static assessment ones.

Additionally, using dynamic assessment can help EFL learners to feel more relaxed and comfortable during the exam session. In contrast to static assessment which puts enormous pressure and stress on the learners, dynamic assessment plays a scaffolding role during the assessment process, making the learners feel strong and assured thanks to the help and mediation provided by the EFL teacher/evaluator.

As for the EFL teacher, the study may imply that DA can help the teacher properly understand and analyze the learners' grammatical problems and difficulties; in other words, DA provides the teacher with a clearer idea of his or her students' learning. As a result, this will integrate assessment and instruction together, improving students' effective learning.

\section{SUGGESTIONS FOR FURTHER RESEARCH}

In this study, the researchers only dealt with the grammar component of the target language, while further research is necessary to add more literature to the area of DA research. It is a valuable tool for those practitioners who really wish to fill the gap between teaching and testing, and link them together.

The researchers' suggestions to promote further research are summarized in the following directions:

- Replications of the present study would augment the body of literature and research on dynamic assessment in the context of an EFL classroom. This would help build up a growing body of literature relating to dynamic assessment issues in the area of grammar in particular.

- Replications of the present study with participants across other levels of education would help enrich the DA literature. This suggests that further research on a larger sample from different populations is advisable.

- This study investigated the grammar knowledge of students, while further research can open new avenues of research into other areas such as listening, writing, vocabulary acquisition and so forth.

- The present study focused on group dynamic assessment. To investigate individualized nature of DA would be another area for further research.

\section{REFERENCES}

[1] Abbasi, A., \& Fatemi, M. A. (2015). On The Effect of Dynamic Assessment on Iranian Pre-Intermediate EFL Learners' Acquisition of English Tenses. International Journal of Language Learning and Applied Linguistics World, 8(4), 222-236.

[2] Ableeva, R. (2010). Dynamic assessment of listening comprehension in L2 French. Unpublished doctoral dissertation, The Pennsylvania State University.

[3] Ajideh, P., \& Nourdad, N. (2012). The immediate and delayed effect of dynamic assessment on EFL reading ability. English Language Teaching, 5(12), 141-151.

[4] Aljaafreh, A., \& Lantolf, J. P. (1994). Negative feedback as regulation and second language learning in the zone of proximal development. Modern Language Review, 78, 465-483.

[5] Antón, M. (2003). Dynamic assessment of advanced foreign language learners. Paper presented at the American Association of Applied Linguistics, Washington, D.C., March 2003.

[6] Bekka, K.G. (2010). Dynamic assessment for learning potential: A shift in the focus and practice of evaluating Japanese oral proficiency. Japanese Journal of Education, 10, 53-66.

[7] Chaiklin, S. (2003). The zone of proximal development in Vygotsky's analysis of learning and instruction. In A. Kozulin, B. Gindis, V. S. Ageyev, \& S. M. Miller, (Eds.), Vygotsky's educational theory in cultural context (pp. 39-64). New York: Cambridge University Press.

[8] Daniels, H. (2001). Vygotsky and pedagogy. London: Routledge Falmer.

[9] Haywood, H. C., \& Lidz, C. S. (2007). Dynamic assessment in practice: Clinical and educational applications. New York: Cambridge University Press.

[10] Jafary, M. R., Nordin, N., \& Mohajeri, R. (2012). The effect of dynamic versus static assessment on syntactic development of Iranian college preparatory EFL learners. English Language Teaching, 5(7), 149-157.

[11] Kozulin, A. (2003). Psychological tools and mediated learning. In A. Kozulin, B. Gindis, V. S. Ageyev, \& S. M. Miller (Eds.), Vygotsky's educational theory in cultural context (pp. 15-38). New York: Cambridge University Press. 
[12] Kozulin, A., \& Garb, E. (2002). Dynamic assessment of EFL text comprehension. School Psychology International, 23(1), 112127.

[13] Lantolf, J. P., \& Poehner, M. E. (2011). Dynamic assessment in the classroom: Vygotskian praxis for second language development. Language Teaching Research, 15(1), 11-33

[14] Lantolf, J. P., \& Poehner, M. E. (2008). Dynamic assessment. In E. Shohamy, \& N. H. Hornberger, (Eds.), Encyclopedia of language and education (pp. 273-284). Berlin: Springer.

[15] Lantolf, J. P., \& Poehner, M. E. (2004a). Dynamic assessment of L2 development: Bringing the past into the future. Journal of Applied Linguistics, 1 (1), 49-72.

[16] Lantolf, J. P., \& Poehner, M. E. (2004b). Dynamic assessment in the language classroom. Retrieved from CALPER website: http://calper.la.psu.edu/publications.php.Retrieved 2014/2/1.

[17] Lidz, C.S., \& B. Gindis. (2003). Dynamic assessment of the evolving cognitive functions in children. In A. Kozulin, B. Gindis, V. S. Ageyev, \& S. M. Miller (Eds.), Vygotsky's educational theory in cultural context (pp. 99-116). New York: Cambridge University Press.

[18] Malmeer, E., \& Zoghi, M. (2014). Dynamic Assessment of Grammar with Different Age Groups. Theory and Practice in Language Studies, 4(8), 1707-1713.

[19] Mardani, M., \& Tavakoli, M. (2011). Beyond reading comprehension: The effect of adding a dynamic assessment component on EFL reading comprehension. Journal of Language Teaching and Research, 2(3), 688-696.

[20] Murphy, R. (2008). Dynamic assessment precursors: Soviet ideology and Vygotsky. The Irish Journal of Psychology, 29(3-4), 193-233.

[21] Nasiri, M., \& Khorshidi, S. (2015). Dynamic assessment of formulaic sequences in Iranian EFL learners' writing. International Journal of Language and Applied Linguistics, 1, 26-32.

[22] O'Loughlin, K. (2006). Learning about second language assessment: Insights from a postgraduate student on-line subject forum. University of Sydney Papers in TESOL, 1, 71-85

[23] Oskoz, A. (2005). Students' dynamic assessment via online chat. CALICO Journal, 22 (3), 513-536.

[24] Poehner, M. E. (2008). Dynamic assessment: A Vygotskian approach to understanding and promoting 12 development. Berlin: Springer.

[25] Poehner, M. E. (2007). Beyond the test: L2 dynamic assessment and the transcendence of mediated learning. The Modern Language Journal, 91(3)323-340.

[26] Poehner, M. E. (2005). Dynamic assessment of oral proficiency among advanced L2 learners of French PhD dissertation, Pennsylvania State University.

[27] Poehner, M. E, \& Lantolf, J. P. (2005). Dynamic assessment in the language classroom. Language Teaching Research 9 (3), 233-265.

[28] Poehner, M. E., \& Lantolf, J. P. (2003). Dynamic assessment of L2 development: Bringing the past into the future. CALPER Working Papers Series, (1), 1-26.

[29] Sharafi, M., \& Sardareh, S. A. (2016). The Effect of Dynamic Assessment on Elementary EFL Students' L2 Grammar Learning. Journal of Applied Linguistics and Language Research, 3(3), 102-120.

[30] Sternberg, R.J. \& Grigorenko, E.L. (2002). Dynamic testing: The nature and measurement of learning potential. Cambridge: Cambridge University Press.

[31] Tzuriel, D. (2001). Dynamic assessment of young children. New York: Plenum Publishers.

[32] Wang, T. H. (2010). Web-based dynamic assessment: Taking assessment as teaching and learning strategy for improving students' e-learning effectiveness. Computers \& Education, 54 (4), 1157-1166.

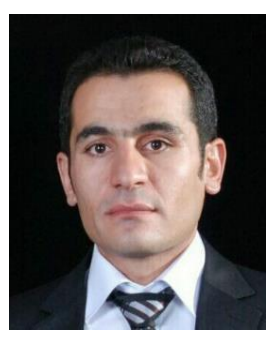

Samran Daneshfar was born in Piran Shahr, Iran. He is an MA graduate of the University of Zanjan, Iran in TEFL. He is currently an experienced EFL teacher in Ministry of Education in Piran Shahr. He is teaching at junior high school. His areas of interest are the Sociocultural Theory and Dynamic Assessment in second language.

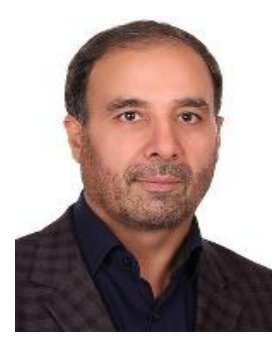

Seyed Hesamuddin Aliasin is an assistant professor of applied linguistics in TEFL at the University of Zanjan, Iran. He obtained his PhD from the University of Tehran, Iran. He presents his research findings at conferences and publishes articles. His main research interests include applied linguistics, SLA, language teaching methodology, language awareness, language assessment, discourse studies, etc. He also, offers courses at undergraduate and graduate levels as well as supervises MA theses on the related areas of interest. 


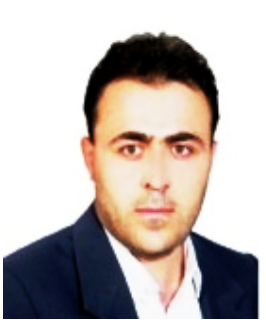

Ali Hashemi is a Ph.D. candidate in TEFL. He is an experienced English teacher and head of ELT board at Zanjan, Iran. The author is currently teaching at high schools. He also works as an instructor at Payam Noor University, Islamic Azad University, and Applied Science Center. He teaches both general English as well as some ESP courses on a variety of fields. His fields of interests include: language skills, ESP material development, and teacher education. 